\title{
A STUDY OF GLACIER-DAMMED LAKES OVER 75 YEARS - BRIMKJELEN, SOUTHERN NORWAY
}

\author{
By D. N. Mottershead
}

(Department of Geography, Portsmouth Polytechnic, Lion Terrace, Portsmouth, Hampshire $\mathrm{PO}_{\text {I }} 3 \mathrm{HE}$, England)

and R. L. Collin

(Department of Geography, University College of Wales, Llandinam Building, Penglais, Aberystwyth, Dyfed SY23 3DB, Wales)

\begin{abstract}
Evidence is brought together concerning the deglaciation of a small valley and the subsequent development in it of periodic glacier-dammed lakes. The respective volumes and drainage dates of the lakes are evaluated, and an attempt is made to relate these to the down-wastage of the impounding glacier.

RÉsumé. Une étude de lacs glaciaires marginaux sur 75 ans à Brimkjelen, en Norvège meridionale. On rassemble des preuves de la déglaciation d'une petite vallée et du développement qui y en est résulté de lacs temporaires derrière des barrages de glace. On estime les volumes et les dates de vidange de ces lacs et on tente de relier ces faits avec les pertes subies par le glacier qui les barrait.

Zusammenfassung. Eine Studie an eisgestauten Seen uber 75 Jahre - Brimkjelen, Sudnorwegen. Zeugnisse über den Gletscherrückgang in einem kleinen Tal und die dadurch ausgelöste Entwicklung von periodischen. eisgestauten Seen werden zusammengestellt. Die jeweiligen Volumina und Abflussdaten der Seen werden ausgewertet; daran schliesst sich der Versuch, eine Beziehung zur Aufzehrung des abdämmenden Gletschers herzustellen.
\end{abstract}

\section{INTRODUCTION}

Brimkjelen is a valley whose outlet is blocked by the trough glacier Tunsbergdalsbreen, some $3 \mathrm{~km}$ above its terminus. This glacier is some ro $\mathrm{km}$ long and is the longest outlet of the ice cap Jostedalsbreen. Brimkjelen is some $2 \mathrm{~km}$ long by $1 \mathrm{~km}$ wide and is itself a former glacial trough incised some $800 \mathrm{~m}$ below the surrounding plateau. At the present time this valley is drained by several streams flowing from the surrounding plateau icefields. These streams converge in Brimkjelen and (in August 1973) flow out through a tunnel beneath Tunsbergdalsbreen.

Brimkjelen is free of glacier ice at the present time, though when Rekstad (I9or [a], [b]) made the first recorded visit to the site in 1900 , a tongue of ice flowed down from the ice fields to join with Tunsbergdalsbreen. The succeeding seventy-five years have seen the recession of this tongue, and the freeing of Brimkjelen from glacier ice. This process has been accompanied by the formation of ice-dammed lakes of varying magnitude within the valley. On many occasions direct observations have been made of such lakes, or their aftermath, at the site. On other occasions the presence of a lake has been inferred from the effects of flooding down-valley in Tunsbergdalen and Leirdalen after the lake has burst out.

The present paper seeks to assemble previous records of Brimkjelen, in order to investigate the pattern and the effect of the shrinkage of glacier ice during recession. Secondly, it aims to determine the magnitude and frequency of resulting ice-dammed lakes, and finally it hopes to offer some constructive remarks on the mechanism responsible for filling and draining the lakes.

\section{SOURCES OF INFORMATION}

The earliest evidence for the presence of lakes in Brimkjelen comes from statements by the inhabitants of Leirdalen, some $8 \mathrm{~km}$ down-valley from the snout of Tunsbergdalsbreen. In Igoo Rekstad (Igor[a], [b]) made the first recorded visit to Brimkjelen, observing the site directly, describing and photographing it. He made a subsequent visit in 1903 (Rekstad, 
1904, 1905). A particularly large flood took place in 1926, and this is described by Rekstad (1927) and Ingstad (1927). Subsequent information is derived from maps and photographs, both aerial and terrestrial, made at a variety of dates between 1937 and the present day. The one exception is the hydrograph record from Leirdalen for June i970, kindly made available by $\mathrm{Hr}$ Christian Nielsen of Norges Vassdrags- og Elektrisitetsvesen. The authors themselves visited Brimkjelen during $197 \mathrm{I}$ and 1973 . These sources of evidence are listed in Table I, together with the nature of the information provided.

TABle I. Summary of information Sources on LaKes in BrimkJelen

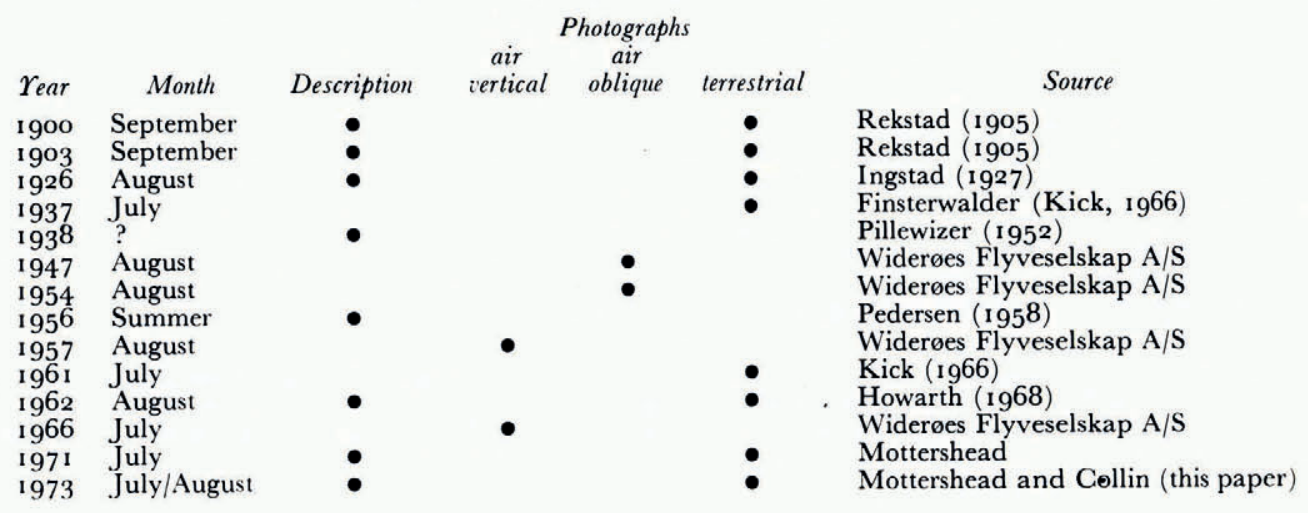

Much of this information provided sufficient evidence for the former extent of Brimkjelen lakes to be mapped, and their volumes estimated. Some sources provide more reliable data for mapping than others, and before discussing the interpretation of the data, it is appropriate to discuss their derivation.

Clearly the ground survey undertaken at Brimkjelen in 1973 was the most accurate survey to date. Using a Zeiss Dahlta oro, a definitive map of the 1973 lake and the ice margin of Tunsbergdalsbreen was completed and subsequently plotted at a scale of $1: 5000$. At the same time, well-marked photographic points within Brimkjelen (on Widerøes Flyveselskap's I 966 photographs) were surveyed in order to effect a connection between the ground survey and subsequent photogrammetric plotting. Such an approach was necessary in view of the logistic problems involved in making a directly surveyed connection with the Norwegian national grid, since most of the local trigonometrical stations are both inaccessible and invisible from Brimkjelen.

Good aerial photography was available from Widerøes Flyveselskap for I957 and I966, at scales of 1 : 35000 and $1: 3^{8}$ ooo respectively, although the former did not include the margin of the plateau ice field. Using a combination of Norwegian trigonometrical stations and check controls surveyed by ourselves, basic topographic and morphological plotting of Brimkjelen at a scale of 1 : 15000 was carried out on a Kern PG2 employing the 1966 photography. Ground verification of the morphological features was carried out in 1973 on photographic enlargements. Figure I shows this basic plot, a combination of the aerial and the ground survey. In addition to the topography and morphology, clear lake and ice margins were plotted off both sets of photography, with the lake margins correct in altitude to around $\pm \mathrm{I}$.o $\mathrm{m}$ relatively, but rather less absolutely.

Next in order of accuracy is the terrestrial photogrammetry carried out by Finsterwalder in 1937 and Kick and Dorrer in I96 I (Kick, I966). Very good correlation between the contour patterns from the aerial and terrestrial photogrammetry allows considerable reliance to be placed on both sets of observations. Finsterwalder's original map indicates clear ice margins 


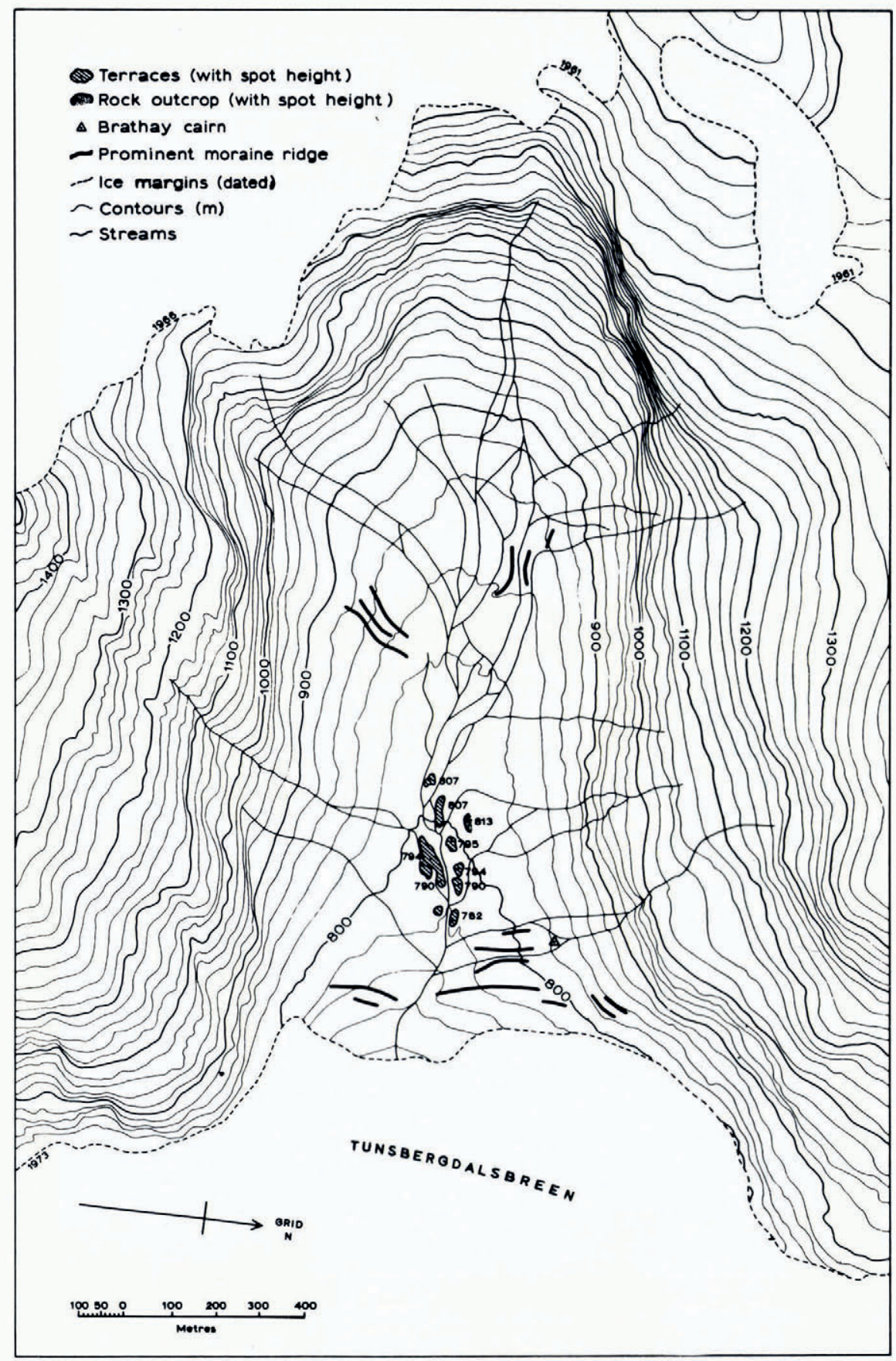

Fig. 1. Brimkjelen, showing basic topographic and morphological features. The ice margins are composite. taken from the most recent information at each location. 

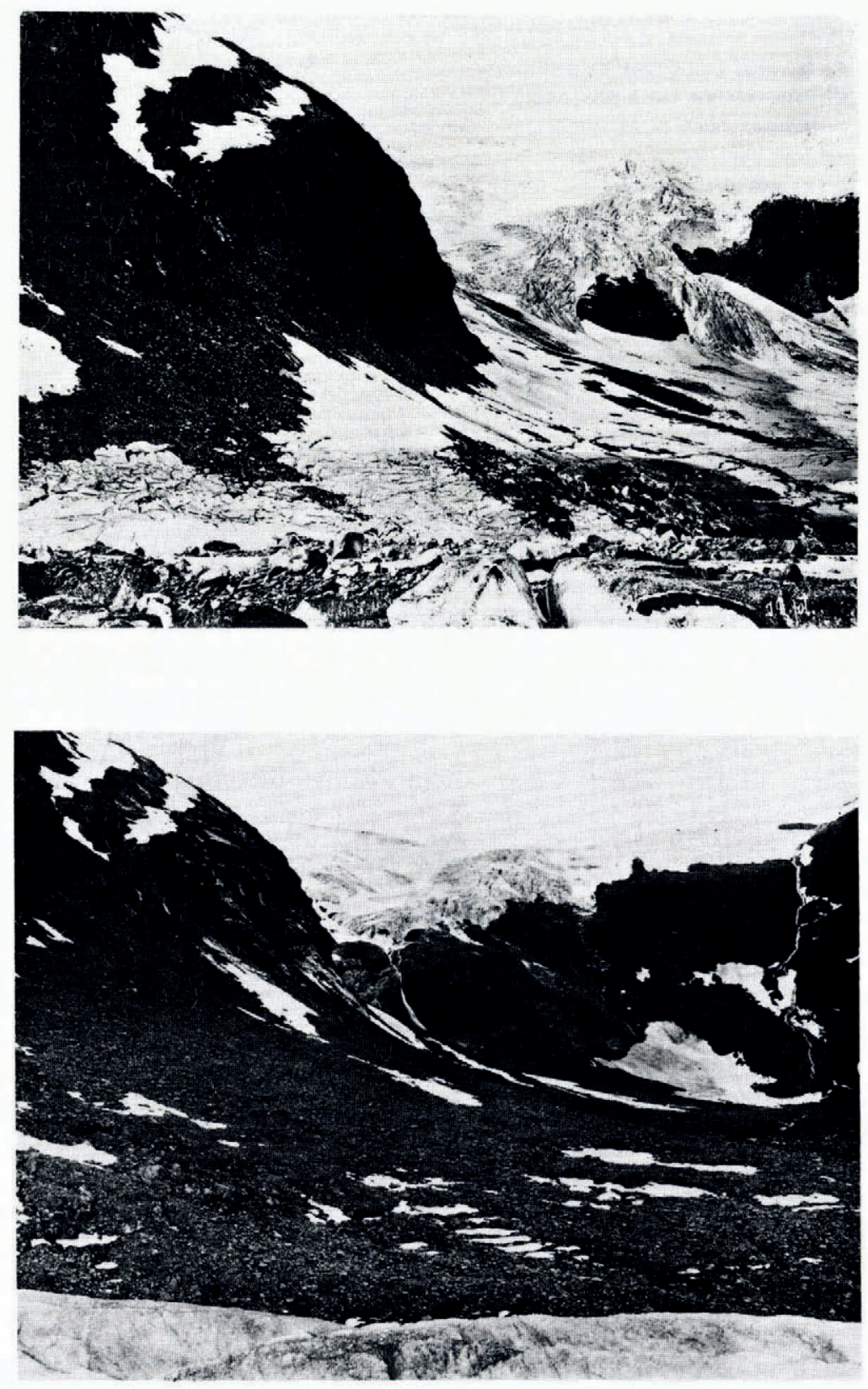

Fig. 2. Rekstad's 1903 photograph (above) compared with one taken in 1973 from approximately the same position. Note the line of fractures in the snow cover in 1903, similar to the fractures in Figure 7. In 1903 glacier ice draining from the plateau icefield covered the floor of Brimkjelen; by 1973 this had shrunk back to the point where it terminated in an ice-fall at the head of the valley. 
at both upper and lower ends of Brimkjelen, with a large lake trapped between. Kick and Dorrer's map is equally clear on ice margins, but, though the presence of a lake in that year is indicated by ice blocks, there is insufficient evidence from which to infer a lake margin.

In using the rest of the evidence from photographs, of critical importance was the unchanging nature of the morphological features within Brimkjelen. To a quite startling degree, such features as groups of large boulders, small terraces, and stream patterns could be positively identified on historic photographs, contemporary photographs and also on aerial photographs. Without this ability to discern common points, much of the photographic evidence would have been of purely qualitative and descriptive interest.

The photograph taken in 1962 by Howarth and its related description (Howarth, 1968), is of considerable value. The highest stranded ice blocks were taken as indicating the greatest extent of an ice-dammed lake. Cross-interpretation with the 1966 aerial photographs on the $\mathrm{PG}_{2}$ allowed an excellent fix to be gained for the lake altitude. This was easily extrapolated to show a large lake extending tongue-like over the surface of Tunsbergdalsbreen, tying up well with Howarth's description.

The photographs and descriptions made by Rekstad in 1900 and 1903 are useful, in addition to being fascinating documents (Fig. 2). At that time a continuous sheet of ice extended down into Brimkjelen with its surface reaching $100 \mathrm{~m}$ lower than that of the main glacier. The lateral extent of this ice tongue was carefully plotted with reference to the 1966 aerial photographs and to photographs taken in 1973 from positions as close as possible to those of Rekstad. Additionally, there is clear evidence in a series of fractures in the ice tongue, that the ice had partially collapsed, presumably as the underlying lake had drained. The height of these fractures was plotted and calculated.

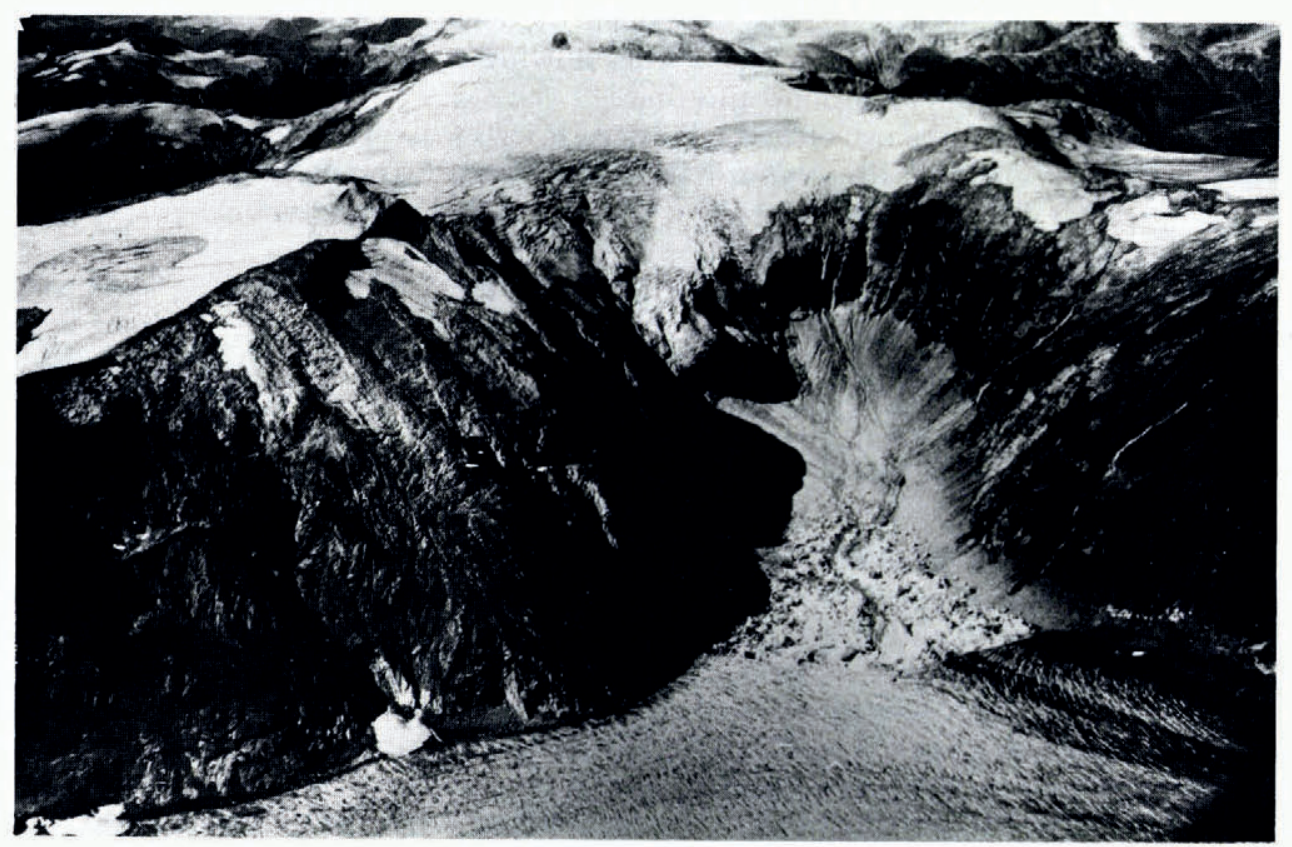

I.ig. 3. (Oblique photograph of Brimkjelen taken from the east, with Tunsbergdalsbreen in the foreground. This is the 1947 oblique referred to in the text and shows clearly the pattern of icebergs deposited by the discharging lake. (Photograph by Fjellanger Wideroe $A / S$ reproduced with permission.) 
Oblique aerial photographs flown in 1947 and 1954 by Fjellanger Widerøe A/S were used in the same way as the ground photographs. A large lake in 1947 and a much smaller one in 1954 were inferred from heights of stranded ice blocks (Fig. 3). However, insufficient evidence could be adduced to fix the ice margins.

Finally, the purely verbal descriptions of the situation in Brimkjelen during 1926 by Ingstad (1927), during $193^{8}$ by Pillewizer (1952), during $195^{6}$ by Pedersen (1958) and during I 97 I by Mottershead (1975) supply corroborative evidence considered elsewhere in this paper.

\section{Glacier fluctuations}

Before discussing the pattern of lake formation, it is first necessary to examine the changes which have taken place in the bodies of glacier ice. In Igoo and I 903 when Rekstad visited the locality, glacier ice flowed into Brimkjelen from the surrounding plateau ice field. It entered the valley down an ice fall at the head of the valley and was confluent with the main ice body of Tunsbergdalsbreen at the lower end. There is a strong suggestion of shrinkage of the valley glacier in Brimkjelen at this time, for Rekstad (1905) states that

"in September Igoo, the glacier surface inside Store Brimkjelen lay about r oo m lower than the front of the main glacier" [translation by Mariana and Julian Howard].

This, however, describes the state of the ice after drainage of subglacial waters, and our photogrammetric reconstruction of the situation at that time suggests that the ice surface within Brimkjelen had stood at c. $885 \mathrm{~m}$ a.s.l., or about $50 \mathrm{~m}$ above the rock floor at the thinnest part of the ice.

In 1926 the picture is rather less clear as to whether the glacier flowing down Brimkjelen was still confluent with Tunsbergdalsbreen. Photographs taken by K. Knudsen illustrating Ingstad's paper (1927) appear to show large blocks of detached ice sitting within Brimkjelen, in between the two respective glaciers. Although the evidence is not entirely conclusive, it would appear that the detachment of the glacier flowing down Brimkjelen by recession from Tunsbergdalsbreen took place around this time.

By 1937 the situation is much clearer. Finsterwalder's map shows a lake nearly $\mathrm{I}$ km long separating the two glaciers. It is impossible to determine the exact terminus of the ice-fall glacier at the head of Brimkjelen, since the ice tongue may be in part submerged beneath the waters of this lake.

Just within the position of the outline of the 1937 glacier, there exist some small moraine ridges up to $3 \mathrm{~m}$ high on both sides of the valley. These have been dated by lichenometry as $194^{2}$, on the assumption that the growth curve of lichens here is the same as in Tunsbergdalen. This lichenometric date does seem in good agreement with Finsterwalder's evidence. By I96I the glacier in Brimkjelen had receded completely. The situation at this time was very similar to the present day, the ice being confined now to the surrounding plateaux with no ice-fall glacier present.

Contemporaneous with these changes taking place in the ice mass within Brimkjelen itself, were the changes undergone by Tunsbergdalsbreen. These indicate both a recession and a lowering of the dam formed by the ice wall of this glacier. It is not possible to fix exactly the position of this 1937 ice front, again for the reason that it may have been obscured beneath a supraglacial extension of the lake, but it is clear that the Tunsbergdalsbre ice extended at least $300 \mathrm{~m}$ beyond its 1973 position into Brimkjelen. Good fixes of the position in the years $1957,1961,1966$ and 1973 show that the recession of Tunsbergdalsbreen has been far from regular. Slight re-advances occurred between 1957 and I 96 I, and between 1966 and 1973. In 1973 moraine ridges of $\mathrm{I}-2 \mathrm{~m}$ in height were present at the base of the ice wall, presumably the result of the more recent advance. Further moraines lie across Brimkjelen at its lower end at distances of up to $200 \mathrm{~m}$ from the 1973 ice margin. These would appear to 


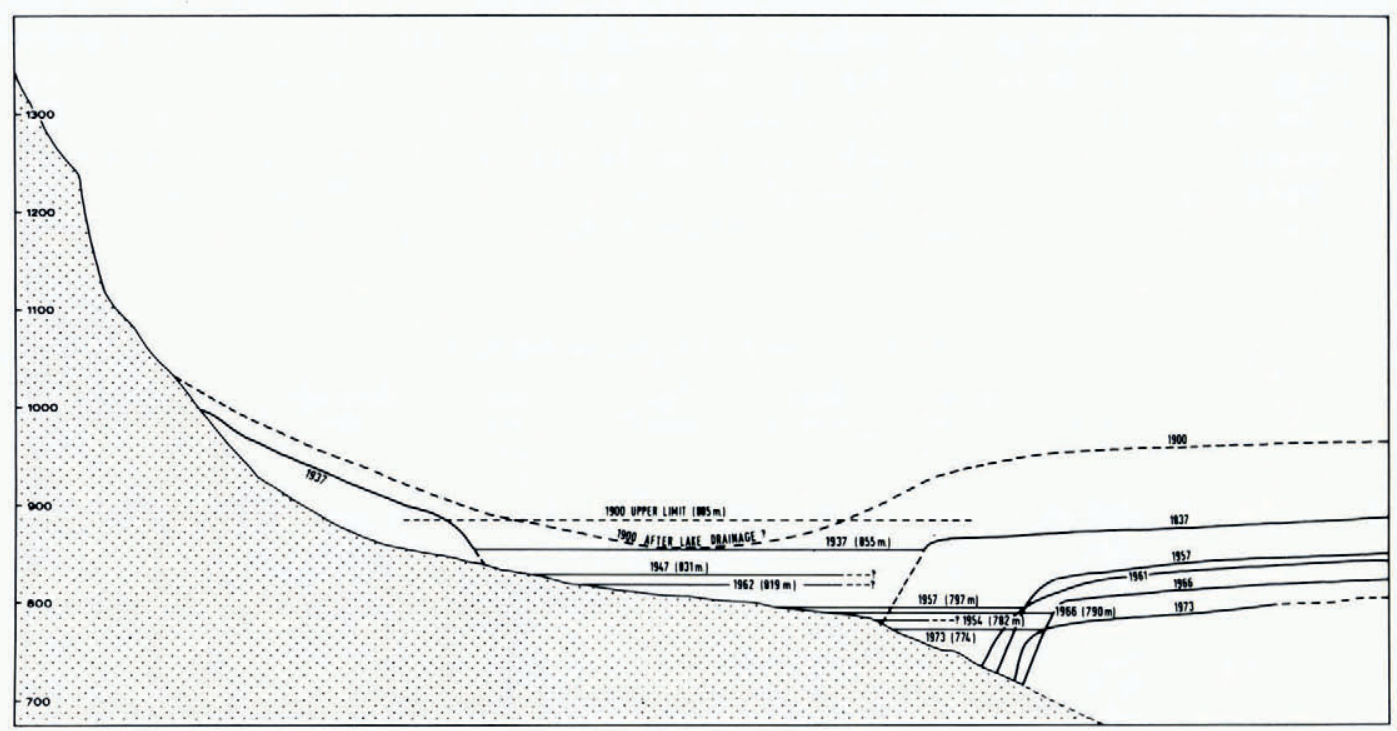

Fig. +. Lomg profile throngh Brimkielen. shouing former glacier and lake lecels. Scale in metres, iertical cxaggeration 2.

indicate that similar fluctuations of the Tunsbergdalsbre margin took place also during the period $1937-57$, for which we have no direct evidence.

In contrast to the fluctuating recession of the margin of Tunsbergdalsbreen, the lowering of its surface appears to have been more regular. Measurement of the surface of the glacier taken from the data plotted in Figure 4, although accurate only to some $5 \mathrm{~m}$ or so (with the exception of the less definite 1900 level), give some idea of the rate of lowering. The figures are summarized in Table II. Though too much should not be read into these data, it appears that the rate of lowering has been gradually increased over the period $1903-66$, with a markedly more rapid rate during $1966-73$. In total the ice surface has lowered by $175 \mathrm{~m}$ between 1903 and 1973 .

The lakes themselves will now be considered against this background of glacier fluctuations, for it is these fluctuations which themselves initiated the formation of the lakes. It should be pointed out at the outset that the evidence for the existence of a lake varies from year to year as summarized in Table III. In several instances, the presence of a lake has been inferred from floods down-valley in Leirdalen, both from historic records and from a stream

TABLE II. TUNSBERgDalsBreEn. LOWERING OF GLACIER SURFACE

$\begin{array}{lcc}\text { Date } & \begin{array}{c}\text { Altitude } \\ \mathrm{m}\end{array} & \begin{array}{c}\text { Lowering } \\ \mathrm{m} / \text { year }\end{array} \\ 1903 & 955 & 2.17 \\ 1937 & 875 & 2.25 \\ 1957 & 830 & 2.50 \\ 1961 & 820 & 3.00 \\ 1966 & 805 & 3.57 \\ 1973 & 780 & \end{array}$


hydrograph in 1970 (personal communication from C. Nielsen). On the basis of both acrial and terrestrial photographs, the presence of several lakes has been inferred from stranded icebergs within the Brimkjelen (Fig. 3). These could only have achieved their observed distribution and position by floating on lake waters - a point made by Pedersen ( $195^{8}$ ). The uppermost point of stranded ice blocks all reaching the same level has been taken as indicating maximum lake level, and is considered accurate to $\mathrm{I} \mathrm{m}$ in altitude. On two occasions alone the presence of a substantial lake has been observed directly, in 1937 and 1973 .

\begin{tabular}{|c|c|c|c|c|c|}
\hline Year & $\begin{array}{c}\text { Flood } \\
\text { observed }\end{array}$ & $\begin{array}{c}\text { Lake } \\
\text { observed }\end{array}$ & $\begin{array}{l}\text { Lake } \\
\text { inferred }\end{array}$ & $\begin{array}{c}\text { Lake } \\
\text { volume } \\
\times \mathrm{IO}^{-6} \\
\mathrm{~m}^{3}\end{array}$ & $\begin{array}{c}\text { Drainage } \\
\text { date }\end{array}$ \\
\hline I 896-99 & $\bullet$ & & $\bullet$ & $<2$ & late July \\
\hline 1900 & $\bullet$ & & $\bullet$ & 2 & 6 August \\
\hline 1903 & $\bullet$ & & $\bullet$ & c. 2 & $22 / 23$ August \\
\hline I 926 & $\bullet$ & & - & $\left\{\begin{array}{l}15^{-20} 0^{*} \\
25^{-} 30^{\dagger}\end{array}\right.$ & I4 August \\
\hline 1937 & & $\bullet$ & & 17.6 & post I 8 July \\
\hline $193^{8}$ & & - & & $<17.6$ & \\
\hline 1947 & & & - & & pre 28 August \\
\hline I 954 & & & $\bullet$ & & pre 24 August \\
\hline I 957 & & & - & 4.2 & pre 6 August \\
\hline 1962 & & & $\bullet$ & 11.5 & pre August \\
\hline I 966 & & & - & $5 \cdot 3$ & pre 28 July \\
\hline I 970 & - & & - & $5 \cdot 7$ & 2 I-23 June \\
\hline I97 I & & & - & & pre 27 July \\
\hline 1973a & & & - & 2.5 & pre 27 July \\
\hline I $973 \mathrm{~b}$ & $\bullet$ & $\bullet$ & & 0.2 & I I August \\
\hline
\end{tabular}

\section{The Sequence of LaKes}

The pattern of lake formation, as far as our fragmentary evidence allows us to interpret, is illustrated in Figure 5. The earliest lakes in Brimkjelen for which there is recorded evidence occurred in the four summers of 1896-99. Rekstad (1905, 1927) states that, in each of these years, floods were observed in Leirdalen during the last part of July. These floods were not paralleled in rivers in adjacent areas, and are thus presumed to have had their origin as outbursts from Brimkjelen. The only indication of their magnitude is that they were less than the flood of 1900 .

In I goo, a flood considerably greater than the previous ones took place. Rekstad (I90I[a]) subsequently visited the site and described the scene in Brimkjelen and the lines of fracturc which indicated the area of ice which had subsided as the underlying water had drained away. Estimating the mean depth of the sunken area as at least $200000 \mathrm{~m}^{2}$, he arrived at a volume for the subglacial lake of $2 \times 10^{6} \mathrm{~m}^{3}$.

A flood of comparable magnitude occurred again in 1903, after two years had intervened with no floods of great consequence. Rekstad (r 904 ) offers no estimate of the magnitude of this flood but the tone of his writing suggests that it was of similar magnitude to that of I 900 .

The next great flood took place in 1926 . This was of noticeably greater magnitude than the previous ones, as it removed the bridge crossing the stream Leirdøla in the valley Jostedalen, a bridge which had stood for approximately ioo years. Ingstad (1927) suggests a lake volume of $25-30 \times 10^{6} \mathrm{~m}^{3}$ on the basis of observation of Brimkjelen after the flood. Rekstad (1927) quotes an estimate by Ing. Ese of $15^{-20} \times 10^{6} \mathrm{~m}^{3}$. Whichever of these estimates is the more accurate, it is clear that the flood in this year was the largest on record. 

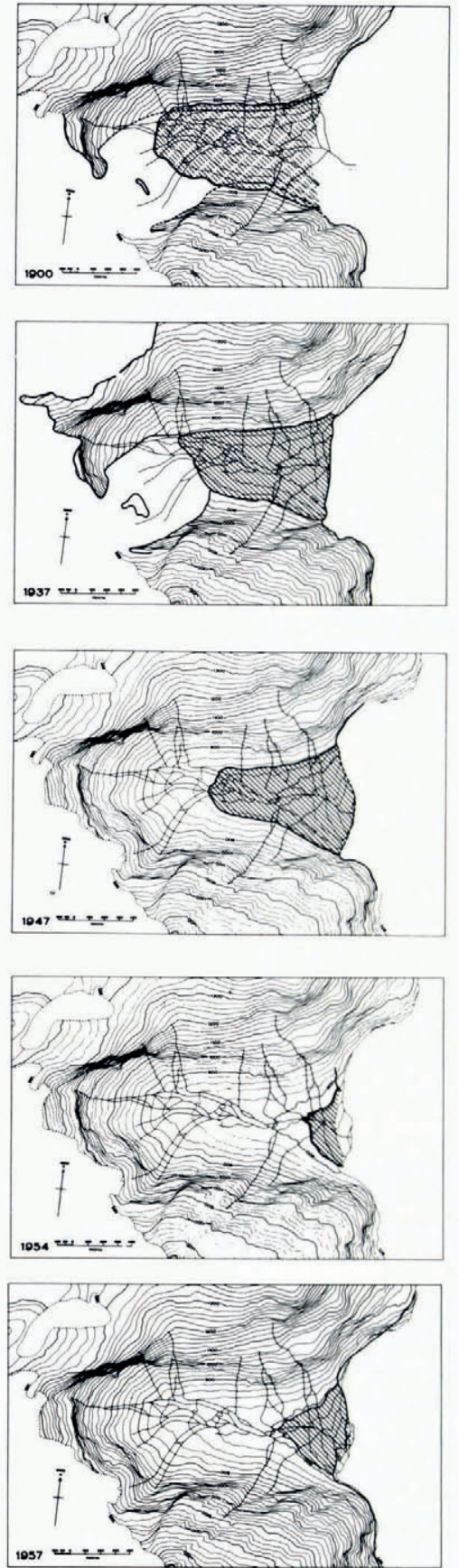
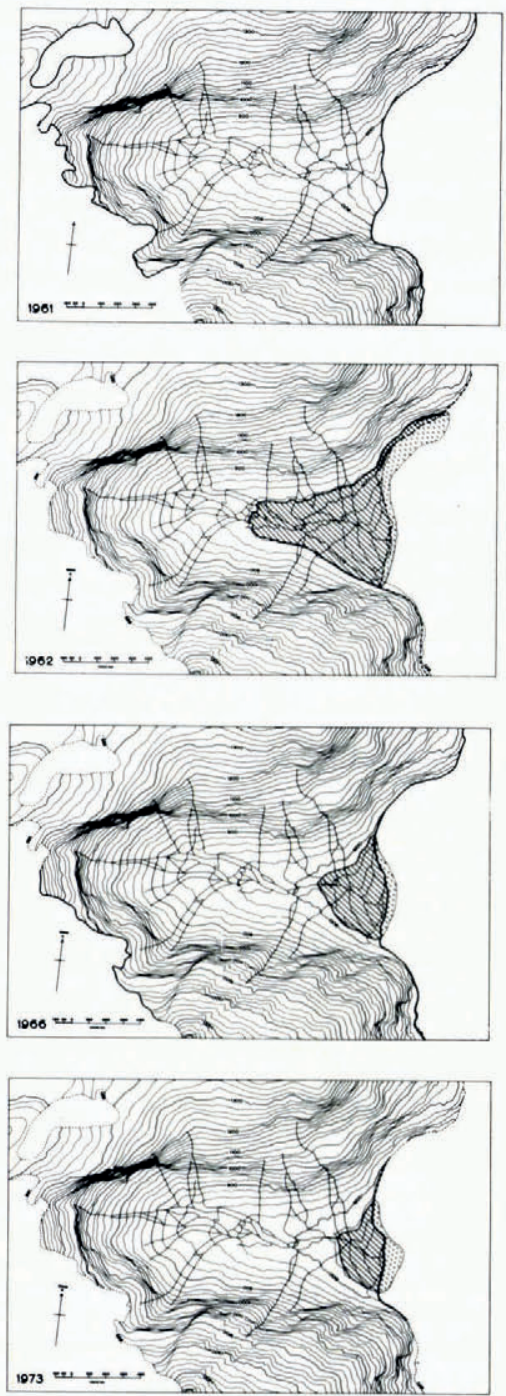

\section{ICE AND LAKE MARGINS IN BRIMKJELEN, 1900-1973}

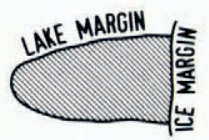

DOTTED LINES

INDICATE LESS CERTAIN POSITION

- CONTOURS > PRINCIPAL STREAMS

Fig. 5. Serial maps of Brimkjelen, showing changes in ice margins and the major lakes. 
Finsterwalder's map provides us with a picture of Brimkjelen in July 1937. Kick (1966) quotes a figure of $19.2 \times 10^{6} \mathrm{~m}^{3}$ for the volume of this lake, although we prefer our figure of $17.6 \times 10^{6} \mathrm{~m}^{3}$, which is derived from planimeter analysis of our more detailed base map. The figure relates to a lake volume, not a flood, and it is clearly possible that the lake increased in volume before draining, this value representing a minimum estimate of the flood magnitude.

For the years 1947 and 1954 stranded icebergs suggest that lakes existed to levels of $831 \mathrm{~m}$ and $782 \mathrm{~m}$ respectively. Unfortunately from the evidence available, it is not possible accurately to fix the Tunsbergdalsbre ice front, and thus no volume can be calculated.

The 1957 aerial photography reveals by stranded ice blocks the former existence of a lake. We calculate the lake level to have reached $797 \mathrm{~m}$, and with a good fix on the 1957 ice margin this indicates a volume of $4.2 \times 10^{6} \mathrm{~m}^{3}$.

Howarth (1968) describes the evidence for a lake in the Brimkjelen for 1962 . The position of stranded ice blocks is clearly shown in a photograph in his paper, and the level of the lake shown by the washed surface of the marginal part of Tunsbergdalsbreen onto which it overflowed. These indicated a lake surface at $8 \mathrm{I}_{5} \mathrm{~m}$, and assuming the position of the ice margin to be similar to $196 \mathrm{I}$ we calculate the volume of the 1962 lake to be $11.5 \times 10^{6} \mathrm{~m}^{3}$.

For 1966 the evidence is again from aerial photographs with good information on the position of the ice margin and the level of stranded icebergs. The level of $790 \mathrm{~m}$ indicates a lake volume of $5.3 \times 10^{6} \mathrm{~m}^{3}$.

In 1970 a flood was recorded by the hydrograph in Leirdalen. Though there are no direct observations of Brimkjelen itself it can reasonably be inferred that the flood represents an outburst of a Brimkjel lake, since no similar flood was recorded on the proglacial stream of the nearby Nigardsbreen. The volume of the flood, and thus of the inferred lake, was $5.7 \times \mathrm{IO}^{6} \mathrm{~m}^{3}$.

The present authors visited Brimkjelen in 1973 and found evidence from which we inferred the former presence of one lake, whilst directly observing the formation and drainage of a second. A small strandline some $3 \mathrm{~cm}$ deep and $10 \mathrm{~cm}$ wide was cut into unconsolidated sandy sediments in Brimkjelen (Fig. 6), and was paralleled by a faint but similar feature on the surface of Tunsbergdalsbreen at the same altitude $(774 \mathrm{~m})$. This indicates a supraglacial extension of the lake, similar to that described by Howarth for 1962. In addition the continuous snow cover around the slopes of Brimkjelen showed a consistent fracture at the same height. Beneath this level the snow was distributed down the slopes in a field of isolated fractured blocks (Fig. 7). This is interpreted as a snow cover formerly extending across a frozen lake surface and let down as the lake drained. The volume of the lake indicated by this evidence is $2.5 \times 10^{6} \mathrm{~m}^{3}$.

During 10 and I I August of the same year a small lake of $0.2 \times 10^{6} \mathrm{~m}^{3}$ was observed to form and drain. This lake has been described elsewhere (Mottershead, 1975). Although only small in comparison with previous lakes, it does indicates that more than one lake can form in a given year.

Such then is the record of lakes for which we have reasonable volumetric evidence. It seems probable that the floods were a regular annual event, at least during the earlier part of the century. Ingstad refers to the autumn floods expected from the glacier, as though they were a regular event. Liestøl (I956) states that the floods continued annually until I949. A major problem is what happened in the years intervening between the recorded floods. The early flood of 1900 excited local comment because of the damage it caused, yet Rekstad's estimate of $2 \times 10^{6} \mathrm{~m}^{3}$ for this flood could make it the smallest of all recorded annual floods. It is possible that this figure represents an underestimate and that floods of similar magnitude subsequently failed to attract attention. The 1926 flood damaged structures which had previously remained intact, and thus was probably the largest event up until this time. Yet the 1937 lake was of the same order of magnitude and no mention of any flood at this time appears in the literature. 


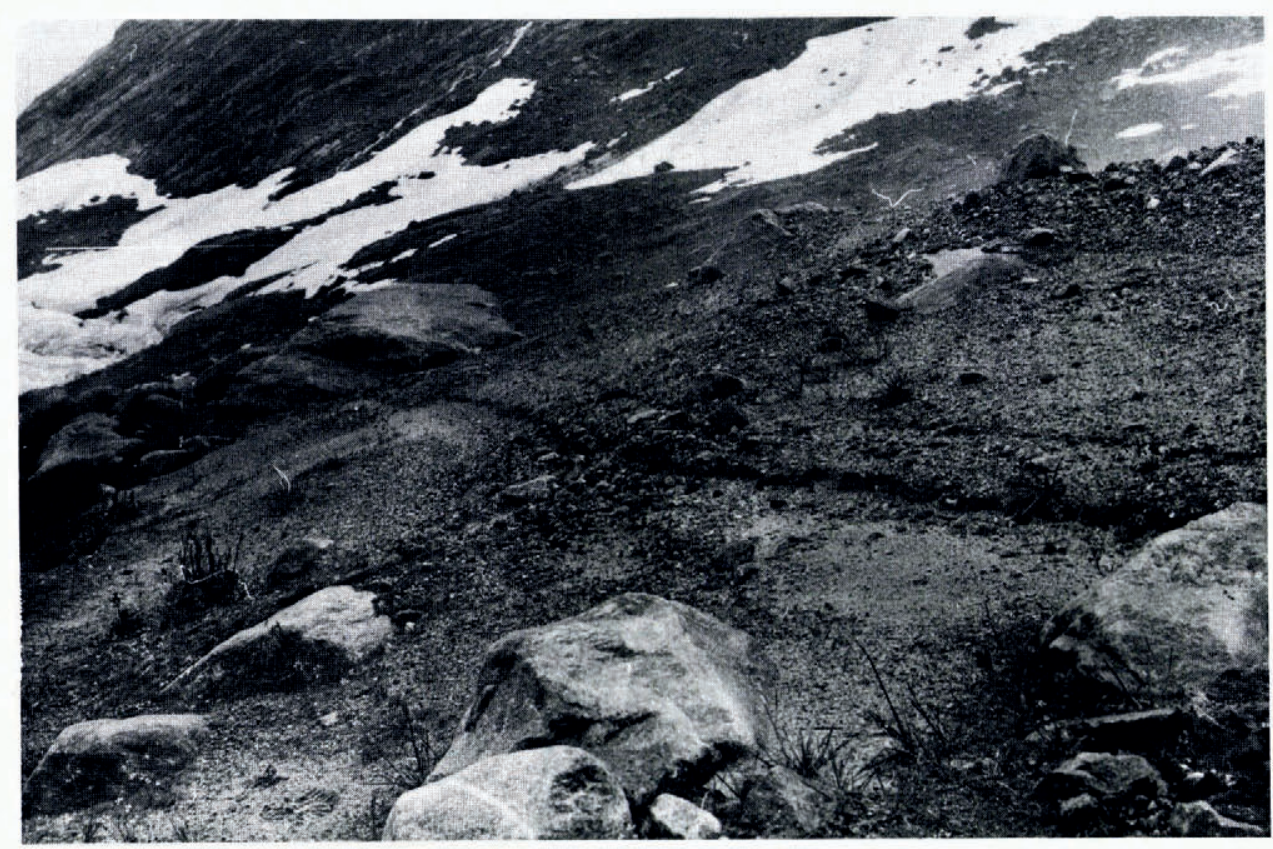

Fig. 6. Mimiature strand lint. indrating early 1973 lahe margin.

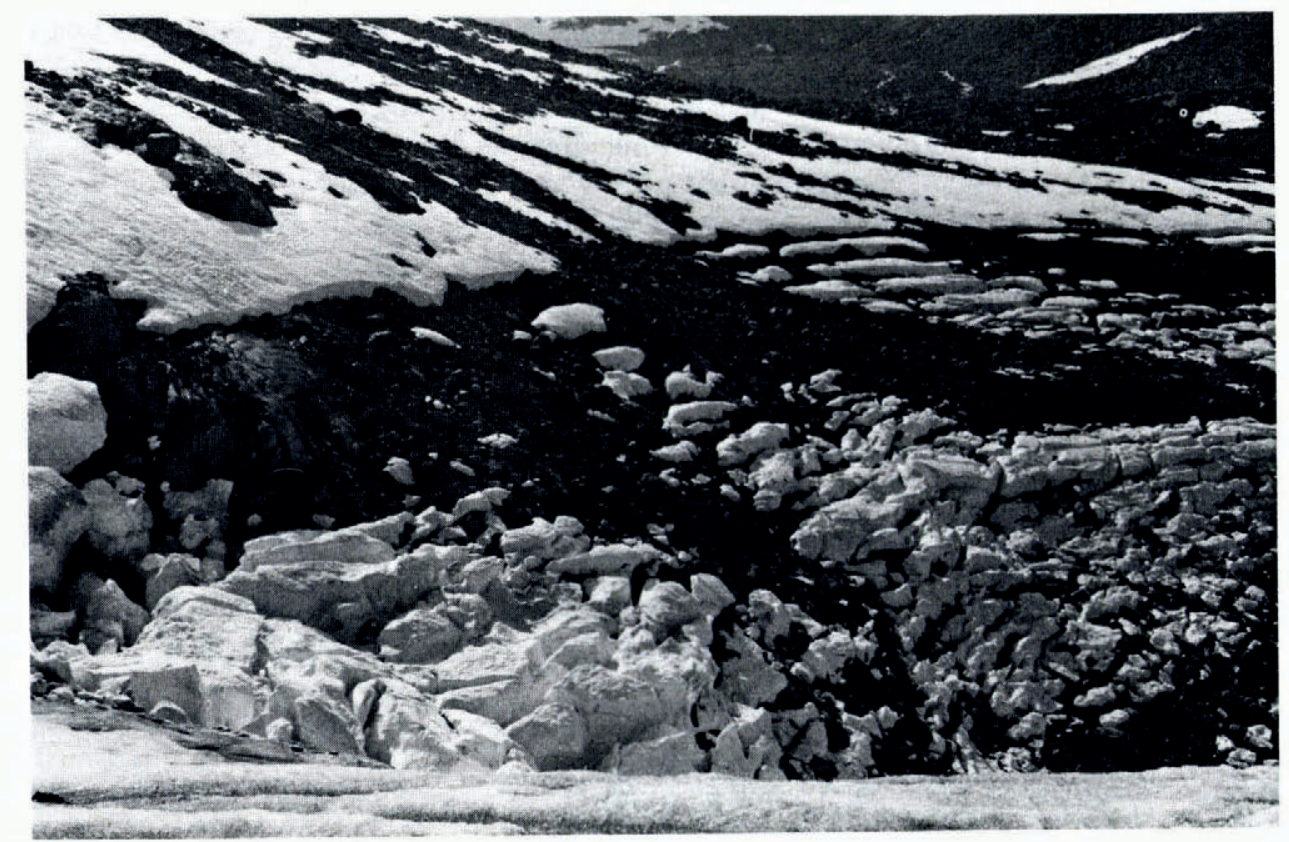

Fig. 7. Brimkjelen 27 July 1973; note the fracture line in the snowe cover at a consistent altitude. and the fractured sume blocks beneath. 
What happened in the intervening years is important in interpreting the pattern of floods. On the one hand it may be that the large floods documented were isolated events; alternatively it may be that they are part of a series of floods of increasing magnitude, decreasing in more recent years. If the latter were the case then it may be only each new peak event which created interest.

The general pattern of lakes throughout the years, as far as it is possible to deduce it from available evidence, is as follows. Conditions conducive to the collection of water first occurred in 1896 , and during the subsequent decade at least, this water was ponded up by Tunsbergdalsbreen subglacially beneath the Brimkjel glacier. As this receded, an open lake formed, and it appears that it was during this phase that the greatest lakes formed, as evidenced by the data for 1926 and 1937. Subsequently as the ice dam of Tunsbergdalsbreen has receded and lowered, the lakes have been of much lower magnitude, although in all cases except the brief August 1973 lake they were larger than Rekstad's estimate for I 900 . At least two of the open lakes extended up on to the surface of the impounding Tunsbergdalsbre.

\section{'THe PATTERn OF DRAinage}

Several observations exist of Brimkjelen in a drained state, and these enable us to look for patterns in the drainage of the lakes. Whereas in the case of several of the early floods we have a precise date of drainage, for many of the more recent lakes we have to deduce that the outburst occurred prior to the date of observation of the drained Brimkjel.

In the years $1896-99$ Rekstad states that the floods occurred at the end of July. The first big flood, in I9oo, occurred on 6 August, whilst the next major outburst, in 1903, took place on 22/23 August. The reason for the later date in the latter case is assumed by Rekstad (1905) to be due to the late spring and cold summer of that year, which would delay ablation processes and thus the lake accumulation would be retarded. Clearly it must be expected that the timing of the ablation season would have such an effect.

The big flood in 1926 took place on 14 August, and, interestingly, a photograph in Ingstad's paper (1927) shows that the water level had begun to rise again only three weeks later.

The 1937 data are the first of a series giving far less precise information. The field work on which Finsterwalder's map was based, showing the lake full, was carried out in the period I 3 -1 8 July. All we can safely deduce is that in this year the lake did not drain until at least I 8 July since mention would surely have been made of the fact had the lake drained before the party left.

For the years 1947 and 1954 the site is shown in the drained state on 28 August and 24 August respectively, indicating that drainage had occurred before these dates. Pedersen (1958) describes Brimkjelen in summer 1956 , unfortunately with no indication of the date. For these years, therefore our information is insufficiently precise to help interpretation.

Howarth's 1962 photograph showing Brimkjelen drained, was taken some time during August of that year. The I 966 aerial photograph, taken 28 July, shows the same. Observation by the present authors on 27 July in both 1971 and 1973 indicated that the lake had drained before that date in both years.

There is thus a general tendency for the largest floods to occur during the month of August. After the floods of the earliest years during the month of July, the big floods of 19oo, I9o3, 1926, and presumably 1937, show a tendency to occur later in the summer. After I954, imprecise though the data are, there is no record of a flood occuring later than 6 August. The only precise record of a flood during this period is from the hydrograph in Leirdalen which shows that in 1970 an outburst took place on $21-23$ June, the earliest of all the recorded dates.

The pattern of dates of drainage therefore appears to offer a close parallel with the volume of lake outbursts, with the largest floods occurring during the later month. This may be 
interpreted in one of two ways. It is possible that a chronological sequence exists in which in the early stages the presence of ice within Brimkjelen limits the volume of water which could accumulate subglacially before the ice lifted and the water drained. During the early years of the open-lake stage, whilst the ice dam was high and tight, large lakes could accumulate before drainage. As the ice dam became lower over the years, so the volume of lakes impounded has decreased.

Alternatively it may be that the big floods occurred only in those years when the ice dam remained water-tight longest, and the occurrence of big floods is dependent on such chance factors as the pressure of the Tunsbergdal ice pushing into Brimkjelen, and the associated tightness of crevasses, which may also have delayed opening in cooler summers.

The time of release of the lake water will depend on the resistance of the ice dam in relation to the pressure put on it by the impounded water. In years when the dam is less fast, the water will be released earlier. The pressure of water will depend on the head. As the ice wall has receded over the years so has the shape of the lake basin changed as the convex long profile of the floor of Brimkjelen has been revealed. Thus the volume of water required to build up a given head of water has decreased as the lakes have become more compact. Thus more recent lakes have been smaller in volume.

In addition, calculation of the depth of water impounded in the lakes of 1937, 1957, 1962, I966, and 1973 (spring), has shown that the head of water has been remarkably constant over the years (Table IV). This suggests that once a given pressure is attained at the foot, then a breach in the ice dam is formed and the lake begins to drain. As Howarth (1968) observes, there is evidence for flotation of the Tunsbergdalsbre ice to allow subglacial seepage, and (in other years) also evidence of tunnel formation. The actual mechanism of breaching may therefore differ from year to year.

Table IV. Calculated depth of lakes in Brimkjelen

$\begin{array}{cccc}\text { rear } & \begin{array}{c}\text { Maximum } \\ \text { lake level } \\ \text { m a.s.l. }\end{array} & \begin{array}{c}\text { Height of } \\ \text { ice foot } \\ \text { m a.s.l. }\end{array} & \begin{array}{c}\text { Head } \\ \text { of water } \\ \mathrm{m}\end{array} \\ 1937 & 855 & 778 & 77 \\ 1957 & 797 & 728 & 69 \\ 1962 & 819 & 735 & 84 \\ 1966 & 790 & 715 & 75 \\ 1973 & 794 & 720 & 74\end{array}$

\section{Discussion}

It has been argued by Liestøl (1956) and more recently by Mathews (r973) that the subglacial drainage of a lake will create and enlarge a subglacial tunnel. Implicit in this argument is that drainage of the ice-dammed lake will be complete. This is substantiated by flood hydrographs which rise increasingly to a peak, and then terminate suddenly (Whalley, I97 I; Mathews, I973; Mottershead, I975). If the supply of water ceases, then the subglacial tunnel will tend to close (Nye, 1973) by plastic deformation of the ice, and any further addition to the lake denied an outlet. Thus shortly after draining the lake may begin to fill again. Several observations have shown Brimkjelen in this state-Pillewizer (1952) mentions a lake level in 1938 considerably lower than the previous year. Ingstad (1927) remarks that the lake had begun to refill some three weeks after the 1926 flood. Pedersen (1958) in 1956 , Howarth (1968) in 1962, and the present authors in 1971 , saw the site also with only a small volume of water in the bottom of the bowl. It would appear that 1973, with the Brimkjel stream draining continuously beneath Tunsbergdalsbreen and maintaining an open tunnel, was the exception in this respect (Fig. 8). 


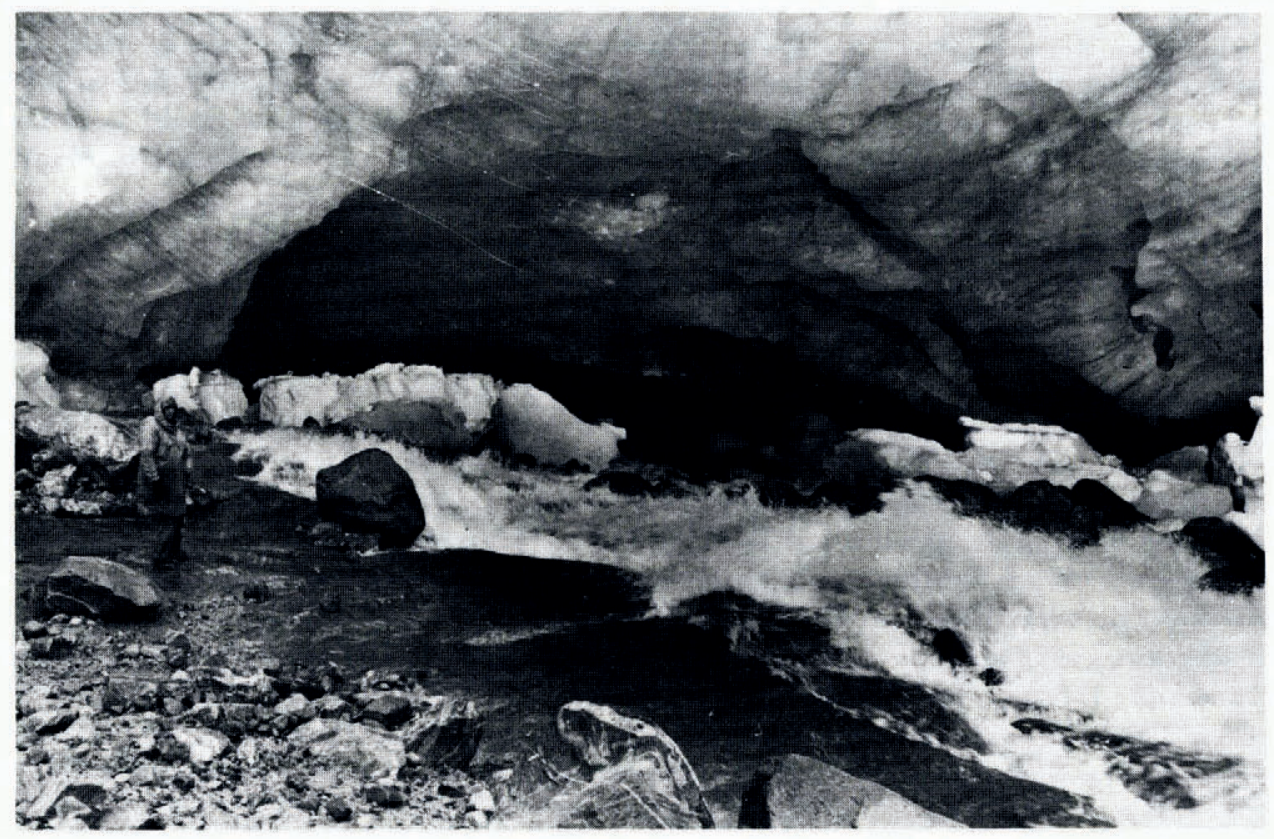

lig. 8. Drainage of the Brimkjel stream into a subglacial tumnel within Tumsbergdalsbreen. Angust 1973 (note figure at left).

It would appear therefore that the lakes have normally begun to fill during the latter part of the summer. Presumably little increase takes place during the winter months, until the spring thaw. During the early part of the summer the lake can be expected to rise rapidly, until the point of drainage is reached. Clearly the volume of water which has accrued prior 10 the outburst will depend largely on the date of the latter. Whether the model outlined carlier is generally applicable, or whether the fluctuation in size of the Brimkjel lakes is a chance process, can only be tested by similar observations of other such sites.

\section{ACKnOWledgements}

Fieldwork was undertaken during 1971 and 1973 as part of the Portsmouth Polytechnic Department of Geography Tunsbergdal Expeditions. Financial contributions are gratefully acknowledged from Portsmouth Polytechnic, the 2oth International Geographical Congress Fund, the Gilchrist Educational Trust, the World Expeditionary Association, I.B.M., and the Green Shield Trading Stamp Company.

Gerald Spraggs, Philip Sanders, Peter Austin and Mark Hurst assisted with field-data collection, under conditions of some discomfort.

Dr P. Worsley generously brought to our attention the photographs by J. Rekstad which are reproduced by kind co-operation of Professors K. Fægri and B. Sturt of the Geologiskc Institutt at the Universitet Bergen, and Mr Harry Walkland of the Department of Geography, University of Reading.

Thanks are due to Dr G. Ostrem for comments on an earlier version of the manuscript, and to Mr Christian Nielsen for providing hydrograph details from Leirdalen.

The diagrams were produced by the Cartographic Drawing Office, University Ciollege of Wales, Aberystwyth.

ISS. received 24 November 1975 and in revised form 20 February 1976 


\section{REFERENC:ES}

Howarth. P. J.. 1968. A supraglacial extension of an ice-dammed lake. Tunsbergdalsbreen. Norway. Journal of Glaciolog). Vol. 7. No. 51. p. 413-19.

Ingstad. O. 1927. Flommen fra Brimkjelen. lorske Turistforenings Arbok. 1927. p. $138-44$.

Kick. W. 1966. Long-term glacier variations measured by photogrammetry. A re-survey of Tunsbergdalsbreen after 24 years. Journal of Glaciolog). Vol. 6. No. 43. p. 3-18.

liestol. O. 1956. Glacier dammed lakes in Norway. Torsk Geografisk Tidsskrift. Bd. 15. Ht. $34.1955-56$. p. $122-49$.

Mathews, W. H. 1973. Record of two jökulhlaups. Linion Géodésique el Géophysique Internationale. Association Internationale d'Hydrologie Scientifique. Commission de leiges et Glaces. Symposium on the Hydrology' of Glaciers. Cambridge, 7-13 September 1969, p. 99-110.

Mottershead, D. N. 1975. Observation of a temporary ice-dammed lake. Brimkjelen. southern Norway. Vorsk Geografisk Tidsskrift, Bd. 29. Ht. 2, p. 69-74.

Nye, J. F. 1973. Water at the bed of a glacier. Union Géodésique et Géophysique Internationale. Associntion Internationale d'Hydrologie Scientifique. Commission de . Veiges et Glaces. Symposium on the Hydrolog) of Glaciers, Cambridge. 7-13 September 1969. p. 189-94.

Pedersen, O. C. 1958. I kjolige omgivelser. Bergen Turlag Arbok. 1958, p. 1 49-55.

Pillewizer. W. 1952. Beobachtungen am Jostedalsbre in Südnorwegen. Zeitschrifi für Giletscherkunde und Glazialgeologie. Bd. 2. Ht. 1. p. 25-34.

Rekstad. J. 1901|a]. Iagttagelser fra bræer i Sogn og Nordfjord. . Vorges Geologiske Undersekelse. Bd. 34. 3. p. 1 - 48.

Rekstad. J. Igor|b|. Opdamning ved Tunsbergdalsbraen i Sogn. Vaturen. Bd. 25. 3. p. 81 87.

Rekstad. J. 1904. Opdamning ved Tunsbergdalsbraen i Sogn. Vaturen, Bd. 28. 1. p. 1-6.

Rekstad, J. 1905. Fra Jostedalsbraen. Bergens. Museums Aarbok. 1904. 1. p. 195.

Rekstad, J. 1927. Den voldsomme flom fra Tunsbergdalsbre. Bergens Museums Arbok. 1926. 4. p. 5 10.

Whalley, W. B. 1971. Observations of the drainage of an ice-dammed lake-Strupvatnet. Troms. Norway. liorsk Geografisk Tidsskrift. Bd. 25, Ht. 3-4. P. 16574 . 